\title{
Quality assessment of mixed fruit squash: physico-chemical analysis, sensory evaluation and storage studies
}

\author{
J. S. Jothi ${ }^{1^{*}}$, P. Karmoker ${ }^{2}$ and K. Sarower ${ }^{2}$ \\ ${ }^{1}$ Department of Food Processing and Engineering, Chittagong Veterinary and Animal Science University, Chittagong- \\ 4225, Bangladesh and ${ }^{2}$ Department of Food Technology and Rural Industries, Bangladesh Agricultural University, \\ Mymensingh-2202, Bangladesh, *Email: juthi.engg.bau@gmail.com
}

\begin{abstract}
Fruits and vegetables belong to an essential class of foods that supply human diet with nutritive requirements including vitamins and minerals which are essential for normal body health and function. The study was carried out to determine the physico-chemical analysis and sensory qualities of mixed fruit squash. Carrot (Drocus carota), papaya (Carica papaya) and banana (Musa sapientum) juice were standardized to produce mixed squash which was stored for 9 weeks in sterilized glass bottles at room temperature. Marginal changes in $\mathrm{pH}$, total soluble solids, acidity and vitamin C were observed. Estimation of vitamin C content $(6.32-15.45 \mathrm{mg})$ of mixed squash showed high improvement in nutritional value of papaya juice incorporated with carrot and banana juice in squash. TSS (40.0 to 41.6) increased with gradual passage of storage time, which might be due to hydrolysis of polysaccharides into monosaccharide and oligosaccharides. The titratable acidity $(1.25 \%$ to $2.97 \%)$ increased and $\mathrm{pH}(5.01$ to 3.87$)$ decreased progressively during the storage period might be due to the excessive fermentation and presence of lactic acid reducing micro- organism. The mean overall acceptability scores of more than 8 for mixed squash prepared up to $40 \%$ carrot juice incorporation with $40 \%$ papaya and $20 \%$ banana juice indicated the commercial scope for manufacturing good and nutritious squash from carrot, papaya and banana juice. However, the shelf life of mixed squash was established within 8 weeks. The product is recommended for children, youth and elderly persons to be used within 8 weeks.
\end{abstract}

Keywords: Quality assessment, Mixed fruits, Squash, Shelf-life

\section{Introduction}

Squash is non-alcoholic concentrated syrup that is usually fruit-flavored and made from fruit juice, water, and sugar or a sugar substitute. Squash must be mixed with a certain amount of water or carbonated water before drinking. Fruit squashes are becoming popular in comparison with synthetic beverages evidently because of their taste, flavor, nutritive value and their storage stability. Among all beverages squash is quite popular all over the world as nutritious soft drinks (Babasaheb, 2000).

Carrot (Daucus carota L. var. sativus) has the highest carotene content of any human foods (Desobry et al., 1998). Carotene, a source of provitamin A, may play a role in protecting the body from numerous diseases that are associated with oxidative stress and damage (Handelman, 2001), and it also has many non-antioxidant properties that a $\square$ ect cellular signaling pathways, modify the expression of some genes and can act as inhibitors of regulatory enzymes (Stahl and Ale-Agha, 2002). To maximize the use of carrot as a source of provitamin A, it is important to find an appropriate processing method to manufacture products that are not only highly preferred by consumers but also are good nutritional sources of provitamin A (Dimitrov et al., 1988).

Papaya (Carica papaya) is a common man's fruits, which is reasonably priced and has a high nutritive value. It is low in calories and rich in natural vitamins and minerals. Papaya places first among the fruits for vitamin C, vitamin A, riboflavin, folate, calcium, thiamine, iron, niacin, potassium and fibre. Papaya when consumed regularly will ensure a good supply of vitamin $A$ and $C$, which are essential for good health especially for eyesight and can help to prevent early age blindness in children (Krishna et al., 2008).

Banana (Musa sapientum L.) is one of the major fruit crops in Bangladesh in respect of production and area (BBS, 2006). It is available throughout the year. Its consumption rate is higher than any other fruit. It is one of the cheapest, delicious and most nourishing of all fruits. It is preferred by people of all ages. The fruits constituents mainly carbohydrates, minerals and water and thus is a rich source of energy. It has also several medicinal properties. Banana is a perishable fruit and considerable amount of it is spoiled. 
The perishability of the fruit is attributed to immense physiological changes after harvest (Momen et al., 1993).

Juice blending is one of the best methods to improve the nutritional quality of the fruits beverages. It can improve the vitamin and mineral content depending on the kind and quality of fruits and vegetables used (De Carvalho et al., 2007).

Keeping in view of the above circumstances an investigation was planned to fulfil the following objectives:

- to develop standard formulation for preparation of mixed fruit squash

- to assess the quality of the mixed fruit squash by physico-chemical analysis and sensory attributes

- to asses shelf life of mixed squash.

\section{Materials and Methods}

\section{Materials required}

The experiment was conducted in the laboratory of the Department of Food Processing and Engineering, Chittagong Veterinary and Animal Sciences University, Chittagong-4225, Bangladesh. The fresh and well graded carrot (Daucus carota), fresh and fully ripe papaya (Carica papaya) and banana (Musa sapientum) and sugar collected from the local market were used in the study. Potassium metabisulphite (KMS), citric acid and other materials required were used from the laboratory stock.

Extraction of papaya juice: Fresh and fully ripe papaya was used for extraction of juice. Papaya was washed thoroughly and peeled. Juice was collected by cutting out the flesh of papaya after removing seeds. The juice was extracted using a high quality electric juicer. The extracted juice was strained properly. Juice was pasteurized at $82-85^{\circ} \mathrm{C}$. After pasteurization juice was cooled properly. Juice was packed properly into high density polyethylene. The packed juice was stored in a deep freeze at a temperature of $-20^{\circ} \mathrm{C}$ for future use.

Extraction of banana juice: Fresh and fully ripe banana was used for extraction of juice. Bananas were peeled and cut into slices. The slices were steam blanched to prevent browning reaction. The juice was extracted using a high quality electric juicer. The extracted juice was strained properly. Juice was pasteurized at $82-85^{\circ} \mathrm{C}$. After pasteurization juice was cooled properly. Juice was packed properly into high density polyethylene. The packed juice was stored in a deep freeze at a temperature of $-20^{\circ} \mathrm{C}$ for future use.

Extraction of carrot juice: Fresh and matured carrot was cleaned to remove dirt, unresidual skin and other undesirable materials. Then it was washed thoroughly, peeled and cut into slices. The slices were blanched in boiling water for 3 minutes. After cooling juice was extracted using a high quality electric juicer. The extracted juice was strained properly. Juice was pasteurized at $85^{\circ} \mathrm{C}$. After pasteurization juice was cooled properly. Juice was packed properly into high density polyethylene. The packed juice was stored in a deep freeze at a temperature of $-20^{\circ} \mathrm{C}$ for future use.

\section{Formulations for squash}

The basic formulations used for preparation of mixed fruits squash are outlined in Table 1.

\section{Specification required}

TSS: $40 \%$; Acidity: $1.25 \%$; Juice: $25 \%$ and $\mathrm{SO}_{2}: 350$ ppm (KMS)

\section{Preparation of mixed fruit squash}

Juice, sugar, citric acid and KMS required were separately weighed. Water was also measured according to the calculation. Small quantity of water was taken out from the measured quantity of water to dissolve KMS later on. Sugar and citric acid were mixed with water and heated to prepare syrup. Filtered the syrup through a coarse cloth and then cooled. KMS was dissolved in aforesaid quantity of water that is measured earlier. Measured juice was then mixed with the cool syrup. Then KMS solution was also added. It was mixed thoroughly and finally squash was prepared. It was then poured in sterilized glass bottle and capped finally. The mixed fruits squash were stored at room temperature. 
Table 1. Formulations used for preparing squash

\begin{tabular}{|l|c|c|c|c|}
\hline \multirow{2}{*}{ Ingredients (\%) } & \multicolumn{4}{c|}{ Samples } \\
\cline { 2 - 5 } & $\mathbf{S}_{\mathbf{1}}$ & $\mathbf{S}_{\mathbf{2}}$ & $\mathbf{S}_{\mathbf{3}}$ & $\mathbf{S}_{\mathbf{4}}$ \\
\hline Papaya juice & 25 & 5 & 10 & 8.25 \\
\hline Carrot juice & - & 15 & 5 & 8.50 \\
\hline Banana juice & - & 5 & 36.266 & 3.25 \\
\hline Sugar & 36.214 & 36.421 & 0.061 & 0.061 \\
\hline KMS & 0.061 & 0.061 & 1.223 & 1.216 \\
\hline Citric acid & 1.225 & 37.30 & 37.45 & 37.66 \\
\hline Water & 37.50 & & & \\
\hline
\end{tabular}

$\mathrm{S}_{1}=$ papaya $(100 \%)$ only

$\mathrm{S}_{2}=$ carrot $(60 \%)$ : papaya $(20 \%)$ : banana $(20 \%)$

$\mathrm{S}_{3}=$ carrot $(40 \%)$ : papaya $(40 \%)$ : banana $(20 \%)$

$\mathrm{S}_{4}=$ carrot $(34 \%)$ : papaya $(33 \%)$ : banana $(33 \%)$

\section{Physico-chemical analysis}

The fresh papaya, carrot, banana, processed squash were analyzed for moisture, TSS, pH, titrable acidity and vitamin-C were determined adopting AOAC (2005) method. Reducing sugar and non-reducing sugar were determined through method illustrated by Ranganna (2011).

\section{Sensory properties}

Initially and periodically, sensory characteristics of all types of squash were evaluated for different sensory attributes by a panel of 15 panelists. All the panelists were briefed before evaluation. Sensory attributes like appearance and color, aroma, taste and overall acceptability for all samples were assessed using nine point hedonic scales. Hedonic scale was in the following sequence: $9=$ Like extremely, $8=$ Like very much, 7 = Like moderately, $6=$ Like slightly, $5=$ Neither like nor dislike, $4=$ Dislike slightly, $3=$ Dislike moderately, $2=$ Dislike very much and $1=$ Dislike extremely (Larmond, 1977). The samples were coded with letters and served to the panelists at random to guard against any bias.

\section{Statistical analysis}

The data obtained from the experiments were statistically analyzed for analysis of variance (ANOVA) and consequently Duncan's Multiple Range Test (DMRT) was used to determine significant difference among the various samples in triplicate. Data were analyzed using the software, Statistical Package for Social Sciences (SPSS) version SPSS 16.0.2 at the 0.05 level (SPSS, 2008).

\section{Microbiological study}

Determination of total plate count (TPC) and total yeast and mold count (TMC): For total viable count of bacteria and counting of total yeast and mold present in mixed fruit squash were determined according to the method as described in the "Recommended Method for the Microbiological Examination of Food" (American Public Health Association, 1966).

Storage studies of mixed fruits squash: The prepared squash was packed in glass bottle and stored in room temperature $\left(26 \pm 3^{\circ} \mathrm{C}\right)$. The packed squash was uncapped at a regular interval to asses through physicochemical changes and sensory test for color, aroma, taste and overall acceptability. The spoilage was determined by organoleptic rejection.

\section{Results and Discussion}

\section{Compositions of papaya juice, banana juice and carrot juice}

The juice extracted from papaya, banana and carrot were analyzed for moisture, total soluble solid, total sugar, $\mathrm{p}^{\mathrm{H}}$, acidity and vitamin $\mathrm{C}$. The results are shown in Table 2. 
Table 2. Composition of juice used for preparation of mixed fruits squash

\begin{tabular}{|l|c|c|c|c|c|c|c|}
\hline Sample & Moisture \% & TSS Brix & Total sugar \% & Reducing sugar \% & pH & Acidity \% & Vit C $\mathbf{~ m g / 1 0 0 g}$ \\
\hline Papaya & 88 & 10 & 8.13 & 5.33 & 5.6 & 0.10 & 61.8 \\
\hline Banana & 72 & 15 & 13.05 & 9.74 & 5.2 & 0.25 & 8.32 \\
\hline Carrot & 88.69 & 7 & 4.91 & 2.15 & 5.9 & 0.05 & 5.87 \\
\hline
\end{tabular}

Composition analysis of juice is required for formulation of fruit squash to calculate the sugar and water requirements. From Table 2 it is seen that banana is very much rich in terms of TSS (15\%) and total sugar $(13.05 \%)$. Whether papaya $(88 \%)$ and carrot $(88.69 \%)$ have similar moisture content but papaya has a distinguishable greater TSS content $\left(10^{\circ}\right.$ Brix) from carrot $\left(7^{\circ} \mathrm{Brix}\right)$. There is a reversible trend observed in $\mathrm{p}^{\mathrm{H}}$ and acidity of the three fruits. Papaya $(61.8 \mathrm{mg} / 100 \mathrm{~g})$ has variably higher vitamin $\mathrm{C}$ content than banana $(8.32 \mathrm{mg} / 100 \mathrm{~g})$ and carrot $(5.87 \mathrm{mg} / 100 \mathrm{~g})$. Similar results were found by Karmoker et al. (2010) and Karmoker et al. (2011). A small difference was found due to be variety, maturity indices and other physiological factor.

\section{Microbial profile of mixed fruit squash}

The microbiological profile of mixed fruit squash are presented on Table 3.

Table 3. Microbial evaluation of mixed fruit squash

\begin{tabular}{|c|c|c|}
\hline Sample code & TPC (cfu/mI) & TMC (cfu/ml) \\
\hline$S_{1}$ & $4 \times 10^{2}$ & 25 \\
\hline$S_{2}$ & $6 \times 10^{2}$ & 22 \\
\hline$S_{3}$ & $5 \times 10^{2}$ & 19 \\
\hline$S_{4}$ & $2 \times 10^{2}$ & 25 \\
\hline
\end{tabular}

$\mathrm{S}_{1}=$ papaya $(100 \%)$ only

$\mathrm{S}_{2}=$ carrot $(60 \%)$ : papaya $(20 \%)$ : banana $(20 \%)$

$\mathrm{S}_{3}=$ carrot $(40 \%)$ : papaya $(40 \%)$ : banana $(20 \%)$

$\mathrm{S}_{4}=$ carrot $(34 \%)$ : papaya $(33 \%)$ : banana $(33 \%)$

There is a very negligible variation in TPC and TMC among the samples at initial stage. So it can be assumed that there is no effect of different fruit juice ratio used in formulations as the total soluble solid is same $(40 \%)$.

\section{Sensory attributes}

The prepared mixed fruit squash samples were tested by a panel of 15 panelists to assess the sensory attributes in terms of color, aroma, test and overall acceptability. The mean sensory score of mixed fruit squash samples are given in Table 4.

Table 4. Mean sensory score of mixed fruit squash

\begin{tabular}{|c|c|c|c|c|}
\hline \multirow{2}{*}{ Sample code } & \multicolumn{3}{|c|}{${ }^{\star}$ Mean scores of sensory attributes } \\
\cline { 2 - 5 } & Color & Aroma & Taste & Overall acceptability $^{7.07^{\mathrm{b}}}$ \\
\hline $\mathbf{S}_{1}$ & $7.05^{\mathrm{b}}$ & $7.11^{\mathrm{b}}$ & $6.98^{\mathrm{b}}$ & $6.28^{\mathrm{c}}$ \\
\hline $\mathbf{S}_{2}$ & $6.27^{\mathrm{c}}$ & $6.39^{\mathrm{c}}$ & $5.98^{\mathrm{c}}$ & $8.19^{\mathrm{a}}$ \\
\hline $\mathbf{S}_{3}$ & $7.91^{\mathrm{a}}$ & $7.96^{\mathrm{a}}$ & $8.18^{\mathrm{a}}$ & $6.41^{\mathrm{c}}$ \\
\hline $\mathbf{S}_{4}$ & $6.12^{\mathrm{c}}$ & $6.84^{\mathrm{bc}}$ & $6.33^{\mathrm{c}}$ & 0.5627 \\
\hline LSD & 0.5893 & 0.5362 & 0.5713 & \\
\hline
\end{tabular}

*Means with different superscripts within a column are significantly different and the same superscripts do not significantly different (NSD) at $p<0.05$.

$\mathrm{S}_{1}=$ papaya $(100 \%)$ only

$\mathrm{S}_{2}=$ carrot $(60 \%)$ : papaya $(20 \%)$ : banana $(20 \%)$

$\mathrm{S}_{3}=$ carrot $(40 \%)$ : papaya $(40 \%)$ : banana $(20 \%)$

$\mathrm{S}_{4}=\operatorname{carrot}(34 \%)$ : papaya $(33 \%)$ : banana $(33 \%)$ 
The sample $S_{3}$ obtained highest score in all quality attributes. Which indicate the carrot and papaya juice in same proportion gave the highest consumer acceptability. In addition of banana juice to this also gave the satisfactory flavor acceptability. A one way analysis of variance was carried out for color, flavor, texture and overall acceptability of the mixed squash samples and results showed that panelists accepted the entire squash samples with the different degrees of acceptability. There is a significant difference found in sample to sample.

\section{Storage studies of mixed fruit squash}

Mixed fruit squash were stored at ambient temperature $\left(26 \pm 3^{\circ} \mathrm{C}\right)$ for a period of 9 weeks and quality parameters were assessed. The samples were coded as $S_{1}, S_{2}, S_{3}$ and $S_{4}$ which were examined at an interval of 15 days during the storage period.

\section{Effect of storage time on the sensory properties of mixed fruits squash}

The storage quality of processed mixed fruits squash (packed in sterilized glass bottle) were evaluated for different sensory attributes by a panel of 15 panelists for the period of 9 weeks when stored at ambient temperature $\left(26 \pm 3^{\circ} \mathrm{C}\right)$. The storage quality evaluation was done for color, aroma, taste and overall acceptability in nine point hedonic scale. The mean score for color, aroma, taste and overall acceptability of the mixed fruits squash are presented in Table 5. The color was discarded in week 9 as shown in the Table 5. The color changed within the storage period may be due to the microbiological and chemical reactions that might have occurred. Flavor is a combination of various sensations derived from foods. Flavor was agreeable for the first eight weeks and redundant were noticed in the ninth week. On the other hand, taste and overall acceptability, the mixed fruits squash was well accepted till the eight weeks. After 9 weeks of storage time, sedimentation was noticed in mixed squash. It also noticed also that higher carrot percent in mixed squash had higher tendency to sediment. It might be the reason to decrease sensory score after eight weeks. The processed mixed fruit squash were organoleptically acceptable up to 8 weeks of storage at ambient temperature. The effects of storage time on the sensory properties of mixed fruit squash are shown in Table 5.

Table 5. The effect of storage time on the sensory properties of mixed fruit squash

\begin{tabular}{|c|c|c|c|c|c|}
\hline Storage Period & Sample code & Color & Aroma & Taste & $\begin{array}{c}\text { Overall } \\
\text { Acceptability }\end{array}$ \\
\hline \multirow{4}{*}{ Initial } & $\mathrm{S}_{1}$ & 7.05 & 7.11 & 6.98 & 7.07 \\
\hline & $\mathrm{S}_{2}$ & 6.27 & 6.39 & 5.98 & 6.28 \\
\hline & $\mathrm{S}_{3}$ & 7.91 & 7.96 & 8.18 & 8.19 \\
\hline & $\mathrm{S}_{4}$ & 6.12 & 6.84 & 6.33 & 6.41 \\
\hline \multirow{4}{*}{2 weeks } & $\mathrm{S}_{1}$ & 7.01 & 7.09 & 6.94 & 7.04 \\
\hline & $\mathrm{S}_{2}$ & 6.25 & 6.35 & 5.96 & 6.23 \\
\hline & $\mathrm{S}_{3}$ & 7.88 & 7.93 & 8.14 & 8.11 \\
\hline & $\mathrm{S}_{4}$ & 6.10 & 6.80 & 6.29 & 6.37 \\
\hline \multirow{4}{*}{4 weeks } & $\mathrm{S}_{1}$ & 6.94 & 7.03 & 6.89 & 6.98 \\
\hline & $\mathrm{S}_{2}$ & 6.21 & 6.30 & 5.90 & 6.18 \\
\hline & $\mathrm{S}_{3}$ & 7.81 & 7.88 & 8.06 & 8.04 \\
\hline & $\mathrm{S}_{4}$ & 6.04 & 6.77 & 6.23 & 6.29 \\
\hline \multirow{4}{*}{6 weeks } & $\mathrm{S}_{1}$ & 6.81 & 6.89 & 6.73 & 6.82 \\
\hline & $\mathrm{S}_{2}$ & 6.03 & 6.17 & 5.76 & 6.01 \\
\hline & $\mathrm{S}_{3}$ & 7.67 & 7.75 & 7.93 & 7.88 \\
\hline & $\mathrm{S}_{4}$ & 5.88 & 6.58 & 6.01 & 6.13 \\
\hline \multirow{4}{*}{8 weeks } & $S_{1}$ & 6.49 & 6.44 & 6.33 & 6.37 \\
\hline & $\mathrm{S}_{2}$ & 5.73 & 5.67 & 5.41 & 5.51 \\
\hline & $\mathrm{S}_{3}$ & 6.95 & 6.98 & 6.94 & 6.92 \\
\hline & $\mathrm{S}_{4}$ & 5.33 & 5.38 & 5.01 & 5.39 \\
\hline \multirow{4}{*}{9 weeks } & $\mathrm{S}_{1}$ & 5.09 & 5.01 & 5.13 & 5.03 \\
\hline & $\mathrm{S}_{2}$ & 4.13 & 4.17 & 4.11 & 4.12 \\
\hline & $\mathrm{S}_{3}$ & 4.32 & 4.48 & 4.41 & 4.49 \\
\hline & $\mathrm{S}_{4}$ & 4.52 & 4.58 & 4.53 & 4.56 \\
\hline
\end{tabular}

$\mathrm{S}_{1}=$ papaya $(100 \%)$ only

$\mathrm{S}_{2}=$ carrot $(60 \%)$ : papaya $(20 \%)$ : banana $(20 \%)$

$\mathrm{S}_{3}=$ carrot $(40 \%)$ : papaya $(40 \%)$ : banana $(20 \%)$

$\mathrm{S}_{4}=\operatorname{carrot}(34 \%)$ : papaya (33\%): banana (33\%) 


\section{Effect of storage time on the physico-chemical properties of mixed fruit squash}

During storage, the changes in TSS, acidity, $\mathrm{pH}$ and vitamin $\mathrm{C}$ were also observed. Results are presented in Table 6.

From the Table 6, it was observed that TSS increased with gradual passage of storage time ranges from $40^{\circ}$ Brix to $41.60^{\circ}$ Brix, which might be due to hydrolysis of polysaccharides into monosaccharide and oligosaccharides. Similar results were also reported by Deka and Sethi (2001) in juice blends and Deka (2000) found an increasing trend in total soluble solids during storage at ambient and low temperature in lime-aonla and mango-pineapple spiced RTS beverages.

There was a significant increase in titratable acidity content during storage ranges from 1.25 to 2.97 (Table 6). This might be due to the fermentation or hydrolysis of sugar and variation of ferment ability of papaya, banana and carrot juice that affected the acidity content of the squash. It was observed that maximum acidity $(2.97 \%)$ was recorded in sample $S_{1}$ and minimum increase $(2.88 \%)$ in acidity was showed in sample $S_{2}$ during 9 weeks of storage. These findings are in conformity with the studies of Jan and Masih (2012) reported that increase in acidity content during storage in juice blend.

Table 6. The effect of storage time on the physic-chemical properties of mixed squash

\begin{tabular}{|c|c|c|c|c|c|}
\hline Storage Period & Sample code & TSS $^{\circ}$ Brix & $\begin{array}{l}\text { Titratable } \\
\text { Acidity \% }\end{array}$ & $\mathrm{pH}$ & Vit C (mg/100 gm) \\
\hline \multirow{4}{*}{ Initial } & $\mathrm{S}_{1}$ & 40.00 & 1.25 & 4.92 & 15.45 \\
\hline & $S_{2}$ & 40.00 & 1.25 & 5.01 & 4.42 \\
\hline & $\mathrm{S}_{3}$ & 40.00 & 1.25 & 4.98 & 7.19 \\
\hline & $\mathrm{S}_{4}$ & 40.00 & 1.25 & 4.55 & 6.32 \\
\hline \multirow{4}{*}{2 weeks } & $S_{1}$ & 40.30 & 1.37 & 4.87 & 15.15 \\
\hline & $\mathrm{S}_{2}$ & 40.10 & 1.36 & 4.97 & 3.73 \\
\hline & $\mathrm{S}_{3}$ & 40.20 & 1.37 & 4.90 & 6.71 \\
\hline & $\mathrm{S}_{4}$ & 40.20 & 1.36 & 4.49 & 5.76 \\
\hline \multirow{4}{*}{4 weeks } & $S_{1}$ & 40.60 & 1.49 & 4.81 & 13.21 \\
\hline & $\mathrm{S}_{2}$ & 40.40 & 1.47 & 4.92 & 3.37 \\
\hline & $\mathrm{S}_{3}$ & 40.50 & 1.48 & 4.84 & 6.01 \\
\hline & $\mathrm{S}_{4}$ & 40.50 & 1.47 & 4.43 & 4.94 \\
\hline \multirow{4}{*}{6 weeks } & $S_{1}$ & 40.90 & 1.92 & 4.63 & 11.81 \\
\hline & $\mathrm{S}_{2}$ & 40.70 & 1.84 & 4.73 & 2.84 \\
\hline & $\mathrm{S}_{3}$ & 40.80 & 1.88 & 4.65 & 5.07 \\
\hline & $\mathrm{S}_{4}$ & 40.80 & 1.86 & 4.25 & 4.03 \\
\hline \multirow{4}{*}{8 weeks } & $S_{1}$ & 41.10 & 2.57 & 4.41 & 8.85 \\
\hline & $\mathrm{S}_{2}$ & 40.90 & 2.48 & 4.53 & 1.97 \\
\hline & $\mathrm{S}_{3}$ & 41.00 & 2.54 & 4.44 & 3.98 \\
\hline & $\mathrm{S}_{4}$ & 41.00 & 2.51 & 4.01 & 3.29 \\
\hline \multirow{4}{*}{9 weeks } & $S_{1}$ & 41.60 & 2.97 & 4.25 & 3.91 \\
\hline & $S_{2}$ & 41.30 & 2.88 & 4.37 & 0.67 \\
\hline & $\mathrm{S}_{3}$ & 41.40 & 2.94 & 4.28 & 1.38 \\
\hline & $\mathrm{S}_{4}$ & 41.50 & 2.91 & 3.87 & 1.09 \\
\hline
\end{tabular}

$\mathrm{S}_{1}=$ papaya $(100 \%)$ only

$\mathrm{S}_{2}=$ carrot $(60 \%):$ papaya $(20 \%):$ banana $(20 \%)$

$\mathrm{S}_{3}=$ carrot $(40 \%):$ papaya $(40 \%)$ : banana $(20 \%)$

$\mathrm{S}_{4}=$ carrot $(34 \%)$ : papaya $(33 \%)$ : banana $(33 \%)$

There was a significant decrease in $\mathrm{pH}$ during storage (Table 6). This might be due to increase in titrable acidity, as acidity and $\mathrm{pH}$ are inversely proportional to each other. It was observed that the $\mathrm{pH}$ during 9 weeks of storage ranges from 3.87 to 4.37 . The variation of $\mathrm{pH}$ occurred due to the variation of acidity during storage period at room temperature. These results are in agreement with Jan and Masih (2012). 
From table 6 , it is seen that sample $S_{1}$ content higher vitamin $C$. This might be due to papaya contained more vitamin $\mathrm{C}$ than banana and carrot. The vitamin $\mathrm{C}$ or ascorbic acid content of squash decreased during storage with the progression of storage period, which was probably due to the fact that ascorbic acid being sensitive to oxygen, light and heat was easily oxidized in presence of oxygen by both enzymatic and non-enzymatic catalyst. At first day vitamin $C$ of the samples were ranged from 4.42 to $15.45 \mathrm{mg} / 100 \mathrm{gm}$, which were gradually decreased 0.67 to $3.91 \mathrm{mg} / 100 \mathrm{gm}$ during 9 weeks of storage. These findings are in agreement with the studies of Jan and Masih (2012).

\section{Conclusion}

The best acceptable formulation of the mixed fruit squash containing $40 \%$ carrot, $40 \%$ papaya and $20 \%$ banana was identified based on the overall acceptability. The increase in TSS and titrable acidity was directly whereas $\mathrm{pH}$ and vitamin $\mathrm{C}$ concentration change was inversely related with storage period. On the basis of the organoleptic acceptability, it may be concluded that formulation of mixed fruits squash is possible to satisfy consumer taste and preferences up to 8 weeks of storage at ambient temperature. After 9 weeks of storage time, sedimentation was noticed in mixed fruits squash. More studies should be conducted to investigate the causes of sedimentation and recover it to increase consumer preferences during storage.

\section{Reference}

American Public Health Association. 1966. Recommended methods for the microbiological examination of foods. Second edition, Publication Office, American Public Health Association (APHA), Cornell University.

AOAC. 2005. Official methods of analysis. Eighteenth Edition, Association of Official Analytical Chemists, Washington, D. C.

Babasaheb B.D. 2000. Handbook of nutrition and diet. Taylor \& Francis Inc, New York, United States, pp. 231-233.

BBS. 2006. Statistical yearbook of Bangladesh. Bangladesh Bureau of Statistics, Ministry of Planning, Dhaka, Bangladesh. pp. 158-159.

De Carvalho, J.M., Maia, G.A. and De Figueredo, R.W. 2007. Development of a blended non-alcoholic beverage composed of coconut water and cashew apple juice containing caffeine. J. Food Qual., 30: 664-681.

Deka, B.C. 2000. Preparation and storage of mixed fruit juice spiced beverage. Ph.D. Thesis, IARI, New Delhi,

Deka, B.C. and Sethi, V. 2001. Preparation of mixed fruit juice spiced RTS beverages. Ind. Fd. Packer, 42(3): 58-61.

Desobry, S.A., Netto, F.M. and Labuza, T.P. 1998. Preservation of beta-carotene from carrots. Critical Reviews in Food Science and Nutrition, 38:381-396.

Dimitrov, N.V., Meyer, C. and Ullrey, D.E. 1988. Bioavailability of b-carotene in humans. The American Journal of Clinical Nutrition, 48: $298-304$

Handelman, G.J. 2001. The evolving role of carotenoids in human biochemistry. Nutrition, 17: 818-822.

Jan, A. and Masih, E.D. 2012. Development and quality evaluation of pineapple juice blend with carrot and orange juice, International Journal of Scientific and Research Publications, Volume 2, Issue 8, pp. 1-8.

Karmoker, P., Saha, T. and Shams-Ud-Din, M. 2011. Processing and preservation of mixed chips from potato, papaya and carrot. Bangladesh Journal of Agricultural Engineering, 22(1\&2): 53-60.

Karmoker, P., Shams-Ud-Din, M., Mondal, S. C. and Haque, M. A. 2010. Processing of mixed fruit bar from mango, pineapple and papaya. Bangladesh Journal of Agricultural Engineering, 21(1\&2): 25-33.

Krishna, K.L., Paridhavi, M. and Patel, J.A. 2008. Review on nutritional, medicinal and pharmacological properties of Papaya (Carica papaya Linn.), Natural product Radiance, Vol. 7 (4), pp. 364-373.

Larmond, E. 1977. Laboratory methods for sensory evaluation of foods. Department of Agriculture Publication Ottawa, Canada.

Momen, M.N., Rahim M.A., Farooque A.M. and Choudhury. M.S.H. 1993. Effect of some coating materials and physical measures on the prolongation of shelf life of banana. Agric., 4(1-2):41-51.

Ranganna, S. 2011. HandBook of analysis of quality control for fruit and vegetable products. $2^{\text {nd }}$ Edition, Tata McGraw Hill Pub. Co. Ltd., New Delhi.

SPSS. 2008. Statistical package for social sciences (SPSS).version SPSS 16.0. SPSS Inc., Chicago, IL, USA.

Stahl, W. and Ale-Agha, N. 2002. Non-antioxidant properties of carotenoids. Biological Chemistry, 383:553-558. 